\title{
Immunolocalization of aromatase P-450 in ovarian tissue from pregnant and nonpregnant mares and in ovarian tumours
}

\author{
E. D. Watson and S. R. M. Thomson \\ Department of Veterinary Clinical Studies, Royal (Dick) School of Veterinary Studies, Easter Bush, Roslin, \\ Midlothian, EH25 9RG, UK
}

\begin{abstract}
Aromatase $\mathrm{P}-450\left(\mathrm{P}-450_{\text {arom }}\right)$ is a crucial regulatory enzyme that is necessary for conversion of androgens to oestrogens. Corpora lutea and follicles were obtained from the ovaries of cyclic mares and from mares at day 20 and days 40-70 of pregnancy. The presence of P-450 arom within specific cell types was investigated by immunostaining to determine potential sites of oestrogen synthesis. Immunoreactivity for $\mathrm{P}-450_{\text {arom }}$ was confined to the granulosa layer of non-atretic follicles $>5 \mathrm{~mm}$ in diameter and to corpora lutea at all stages of the oestrous cycle and during pregnancy. These findings confirm that aromatization of androgens occurs within the granulosa cells of the preovulatory follicle of the mare and that the corpus luteum of the mare has the capacity for oestrogen production if adequate androgen substrate is available. Granulosa cells in ovarian tissue from three mares with granulosa cell tumours showed little staining for P-450 arom ${ }^{\prime}$ which suggests that these tumours have little aromatizing capacity.
\end{abstract}

\section{Introduction}

The mechanism of steroidogenesis by follicles and corpora lutea in mares remains contentious. Originally it was reported that the primary steroidogenic role of granulosa cells in the preovulatory follicle was to produce progesterone, while the theca interna was responsible for oestradiol production (Short, 1962; Channing and Grieves, 1969; Younglai, 1971). The corpus luteum was not thought to produce oestrogen (Short, 1964; Mahajan and Samuels, 1974). However, it was also found that, although granulosa and luteal cells had only a limited capacity to produce oestradiol de novo, they could aromatize androgens to oestradiol in vitro (Ryan and Short, 1965; Mahajan and Samuels, 1974; Al-Timimi et al., 1989). Interaction between cultured granulosa and theca cells from mare follicles was found to be necessary for oestrogen synthesis, and it was then suggested that androgens of thecal origin were aromatized to oestradiol by granulosa cells (Sirois et al., 1991). Although the corpus luteum of the nonpregnant mare is not thought to produce oestrogen (Short, 1964; Mahajan and Samuels, 1974), recent studies in vivo have provided evidence that corpora lutea from mares that are between 35 and 70 days of pregnancy act as a source of oestrogen (Daels et al., 1991).

Granulosa cell tumour is the most common neoplasm of the mare ovary and represents $2.5 \%$ of all equine neoplasms (Sundberg, 1977). These neoplasms are frequently accompanied by behavioural abnormalities that are manifest as anoestrus, nymphomania or stallion-like behaviour. Testosterone concentrations are often increased in mares exhibiting aggressive male-type behaviour and comprise approximately $50 \%$ of

Received 9 February 1996 affected mares (Stabenfeldt et al., 1979). However, concentrations of oestradiol in mares with granulosa cell tumours are variable and are often not related to the behavioural changes (Stabenfeldt et al., 1979). It has been proposed that aromatization of testosterone to oestradiol may be low in affected mares, as mares with very high concentrations of circulating testosterone do not necessarily have concomitantly high oestradiol concentrations (Stabenfeldt et al., 1979). However no studies have determined the aromatase activity of equine granulosa cell tumours.

The development of antibodies against various steroidogenic enzymes has allowed detailed examination of ovarian steroidogenesis in other species, but to date there have been no studies in the mare ovary on the expression of steroidogenic enzymes at the cellular level throughout the oestrous cycle and pregnancy. In the ovarian steroidogenic pathway, aromatase cytochrome P-450 ( $\left.\mathrm{P}-45 \mathrm{O}_{\text {arom }}\right)$ is a crucial regulatory enzyme that is necessary for conversion of androgens to oestrogens. In the present study, ovarian tissue was obtained from mares at various stages of the oestrous cycle, during early pregnancy, and from three mares with granulosa cell tumours, and stained immunohistochemically to detect and localize the cells capable of aromatization.

\section{Materials and Methods}

Follicles and corpora lutea were obtained from 20 pony mares aged 4-18 years and weighing $250-380 \mathrm{~kg}$. The stage of cycle was monitored by daily ultrasonographic examination of the ovaries and uterus. Day of ovulation was designated day 0 . Ovaries were removed by a colpotomy incision as described by Watson and Sertich (1990). Neuroleptanalgesia was induced 
by intravenous administration of romifidine $\left(50 \mu \mathrm{g} \mathrm{kg}^{-1}\right.$; Sedivet, Boehringer Ingelheim L.td, Bracknell, Berks) and butorphanol $\left(25 \mu \mathrm{g} \mathrm{kg}^{-1}\right.$; Torbugesic, Willows Francis Veterinary Ltd, Crawley, Surrey). Flunixin meglumine $\left(1 \mathrm{mg} \mathrm{kg}{ }^{-1}\right.$; Finadyne, Schering-Plough Animal Health Ltd, Watford, Herts) was administered immediately after surgery. Corpora lutea were obtained from between two and six mares in early (days 2-3), and mid- (days 7-12) dioestrus, in the early follicular phase (day 16), 1 day after administration of the prostaglandin $\mathrm{F}_{2 \alpha}$ analogue cloprostenol $(263 \mu \mathrm{g}$; Estrumate, Mallinckrodt Veterinary Ltd, Uxbridge, Middlesex) in mid-dioestrus, and during pregnancy (days 20 and days 40-70). Preovulatory follicles were obtained during oestrus $(n=7)$ and smaller follicles were dissected out of the ovary during dioestrus $(n=5)$. A jugular blood sample was collected from all mares before surgery and the plasma was stored at $-20^{\circ} \mathrm{C}$ until assayed for progesterone. Granulosa cell tumours were obtained from a further three mares by midline laparotomy under general anaesthesia. Serum concentrations of testosterone and oestradiol were determined by a commercial laboratory (SCL Bioscience Services Ltd, Cambridge) in samples taken before surgery from these three mares.

Tissue was embedded in OCT compound (Miles Inc., Elkhart, IN) on cork disks and snap frozen in a slurry of isopentane-dry ice. The samples were then stored at $-70^{\circ} \mathrm{C}$.

\section{Immunostaining procedures}

Sections $(6 \mu \mathrm{m})$ were immunostained using an avidin-biotin complex method described by Watson and Thomson (1996). The primary antibody, which was kindly provided by $\mathrm{E}$. Simpson (University of Texas), was raised in rabbits against synthetic aromatase cytochrome P-450, and used at a final concentration of $50 \mu \mathrm{g} \mathrm{ml}^{-1}$. The chromagen used (AEC; 3-amino-9-ethylcarbazole) produced a red reaction product and the sections were counterstained with Meyer's haematoxylin.

Negative control sections in which the first antibody was replaced with normal horse serum, and positive controls of horse testis, were included with each batch of samples.

\section{Assay of plasma progesterone}

Progesterone concentrations were determined in unextracted plasma using a radioimmunoassay kit (ICN Biomedicals Inc., Costa Mesa, CA) employing an ${ }^{125}$ I-progesterone tracer (Watson et al., 1995). The limit of detection of the standard curve was $0.25 \mathrm{ng} \mathrm{ml}^{-1}$ and the inter- and intra-assay coefficients of variation were 6.0 and $6.8 \%$, respectively.

\section{Results}

Circulating progesterone concentrations in all mares were $>1 \mathrm{ng} \mathrm{ml}{ }^{-1}$ except for mares in early follicular phase and on the day after treatment with prostaglandin $\mathrm{F}_{2 \mathrm{u}}$.

Immunoreactivity for $\mathrm{P}-450_{\text {arom }}$ was confined to the granulosa cells of non-atretic follicles $>5 \mathrm{~mm}$ in diameter (Fig. 1). The granulosa cells of small follicles $<5 \mathrm{~mm}$ in diameter and the lining of atretic follicles did not stain. No staining for

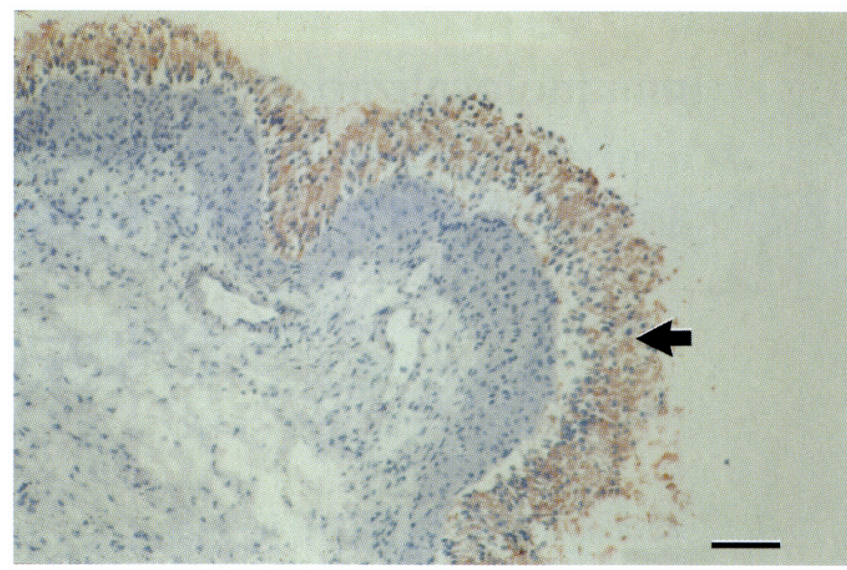

Fig. 1. Immunoreactivity of $\mathrm{P}-450_{\text {arom }}$ in a $30 \mathrm{~mm}$ preovulatory follicle taken from a mare's ovary. Note localization of staining in granulosa cells (arrow). Sections were counterstained with Meyer's haematoxylin. Scale bar represents $10 \mu \mathrm{m}$.

P-450 arom was detected in the thecal cells, stromal cells or preantral follicles.

The early corpus luteum showed many strongly staining luteinizing granulosa cells (Fig. 2a). After structural reorganization of the corpus luteum in mid-dioestrus, there was overall weak immunoreactivity with patchy, strongly stained large cells (Fig. 2b). Cells within the trabeculae did not show staining. On day 16 , when the corpora lutea started to show structural changes associated with luteolysis, they still retained the same staining pattern as in mid-dioestrus. This pattern also persisted in corpora lutea obtained $24 \mathrm{~h}$ after administration of cloprostenol. These staining patterns were consistently present in replicate sections stained on different days.

On day 20 of pregnancy, uniformly pale immunostaining was present. Dark-staining cells were not apparent (Fig. 3a), but by days $40-70$ dark staining cells were again obvious (Fig. $3 \mathrm{~b}$ ). In one secondary corpus luteum removed on day 50 that had ovulated 10 days previously, patches of darkly staining non-luteinized granulosa cells were seen.

Two of the mares with granulosa cell tumours had low testosterone and oestrogen concentrations (testosterone $=0.28$ and $0.06 \mathrm{nmol} \mathrm{l}^{-1}$, oestradiol $=<20 \mathrm{pmol} \mathrm{l}^{-1}$ ) and one had increased concentrations (testosterone $=1.0 \mathrm{nmol} \mathrm{l^{-1 }}$, oestradiol $\left.=230 \mathrm{pmol} \mathrm{l}^{-1}\right)$. Granulosa cells from the tumours of the mares with low testosterone showed very little staining for $\mathrm{P}-450_{\mathrm{arom}}$. Only occasional individual cells were strongly positive (Fig. 4). In the mare with increased concentrations of blood testosterone and oestradiol, occasional groups of granulosa cells showed positive staining.

In sections in which the primary antibody was excluded, there was no evidence of endogenous peroxidase activity (Fig. 5a). In positive controls (testis), interstitial cells stained, whereas no staining was observed in the seminiferous tubules (Fig. 5b).

\section{Discussion}

This is the first report of immunolocalization of $\mathrm{P}-45 \mathrm{O}_{\text {arom }}$ in equine ovarian tissue. A homologous antibody for equine $\mathrm{P}-450_{\text {arom }}$ was not available, but aromatase is known to have 

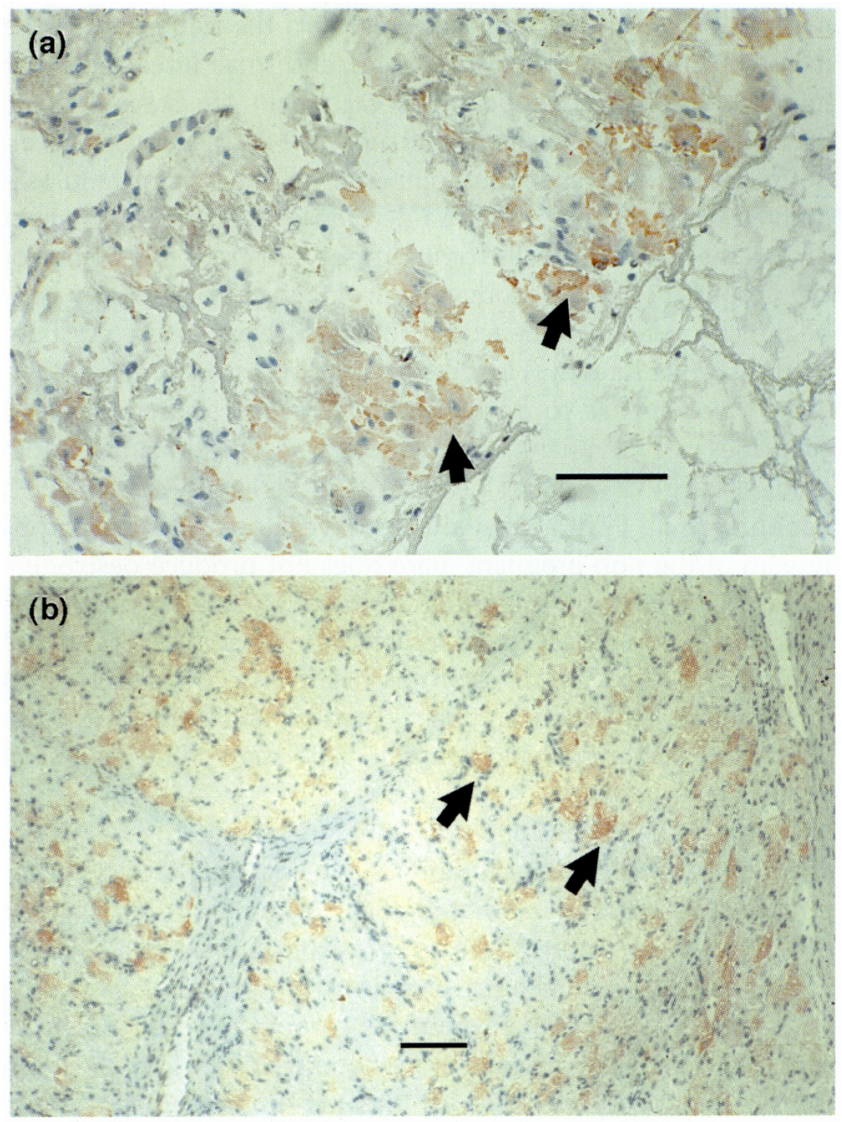

Fig. 2. Immunoreactivity of $\mathrm{P}-450_{\text {arom }}$ in (a) the corpus luteum taken from the ovary of a mare at day 2 of the oestrous cycle. Luteinizing granulosa cells are strongly stained (arrows); and (b) corpus luteum at day 10 of the oestrous cycle. Note the patchy, strong staining localized to individual cells (arrows). Sections were counterstained with Meyer's haematoxylin. Scale bars represent $10 \mu \mathrm{m}$.

wide sequence homology among different species (Simpson et al., 1994) and a heterologous antibody has previously been found to recognize interstitial cells in stallion testes (Eisenhauer et al., 1995). In fact, stallion testis was used as the positive control in our study and staining was confined to interstitial cells as previously reported (Eisenhauer et al., 1995).

Immunoreactivity to $\mathrm{P}-45 \mathrm{O}_{\text {arom }}$ was present in the granulosa cells of medium to large ovarian follicles but was absent in small follicles $(<5 \mathrm{~mm})$. Measurement of steroid concentrations in follicular fluid from mares has shown that highest concentrations are present in large vascularized follicles, with only low concentrations present in small follicles (Short, 1961; Van Rensburg and Van Niekerk, 1968; Channing and Grieves, 1969). This finding is in agreement with the lack of enzyme immunoreactivity in small follicles in our study. Atretic follicles, in which the separate identity of the theca and granulosa cells was lost, showed no evidence of immunoreactive $\mathrm{P}-450_{\mathrm{arom}}$. Concentrations of oestrogen are very low in these follicles (Kenney et al., 1979). Results from cell culture experiments and analysis of steroid content of follicular fluid have led to the conclusion that the theca interna is responsible for oestrogen synthesis in the preovulatory follicle of the mare (Short, 1962; Channing and Grieves, 1969; Younglai, 1971; Hay et al., 1975). However more recent studies have suggested
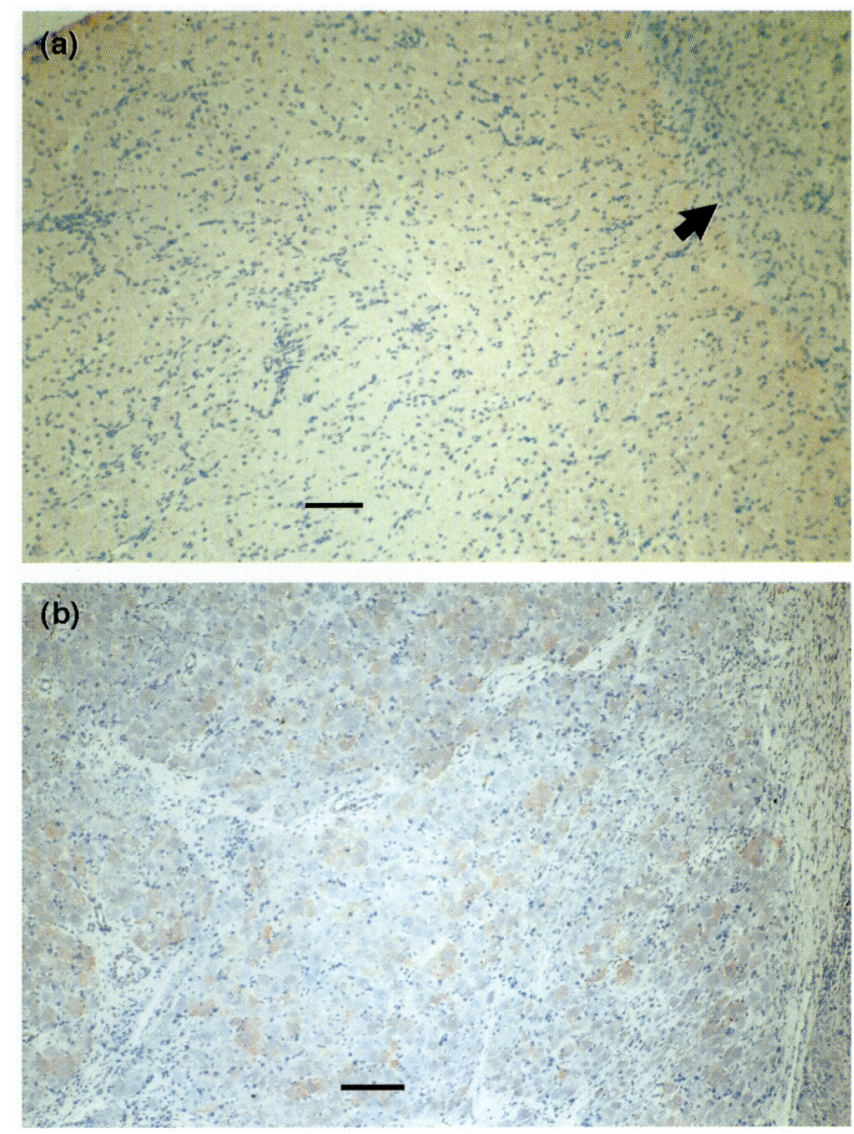

Fig. 3. Immunoreactivity of $\mathrm{P}-450_{\text {arom }}$ in (a) the corpus luteum taken from the ovary of a mare at day 20 of pregnancy. The large cells show uniform weak immunostaining. Note the unstained trabecula (arrow). (b) The corpus luteum at day 70 of pregnancy. Individual large cells are strongly stained. Sections are counterstained with Meyer's haematoxylin. Scale bars represent $10 \mu \mathrm{m}$.

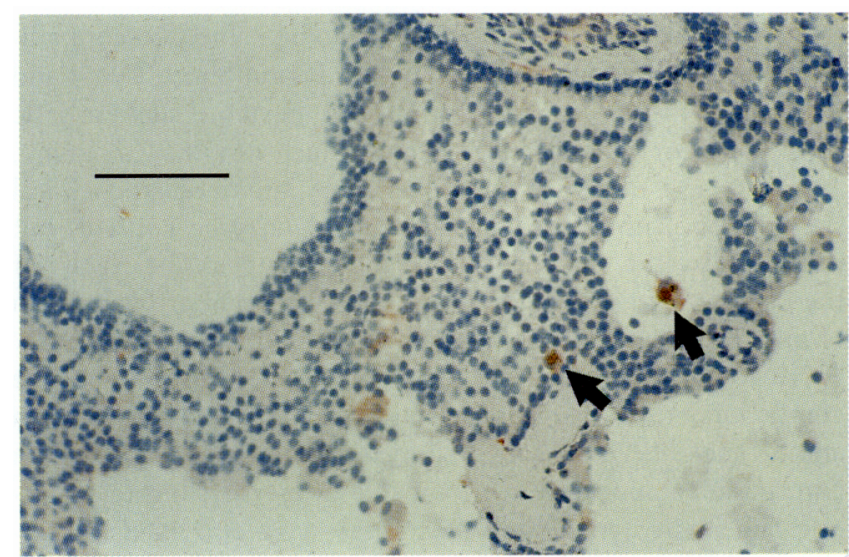

Fig. 4. Immunoreactivity of aromatase P-450 in granulosa cells taken from the ovary of a mare with a granulosa cell tumour. Only a few cells showed strong positive staining (arrows). Scale bar represents $10 \mu \mathrm{m}$.

that testosterone is the main product of cultured equine thecal cells, and that androgens of thecal origin may be aromatized to oestradiol by granulosa cells (Sirois et al., 1991; Tucker et al., 

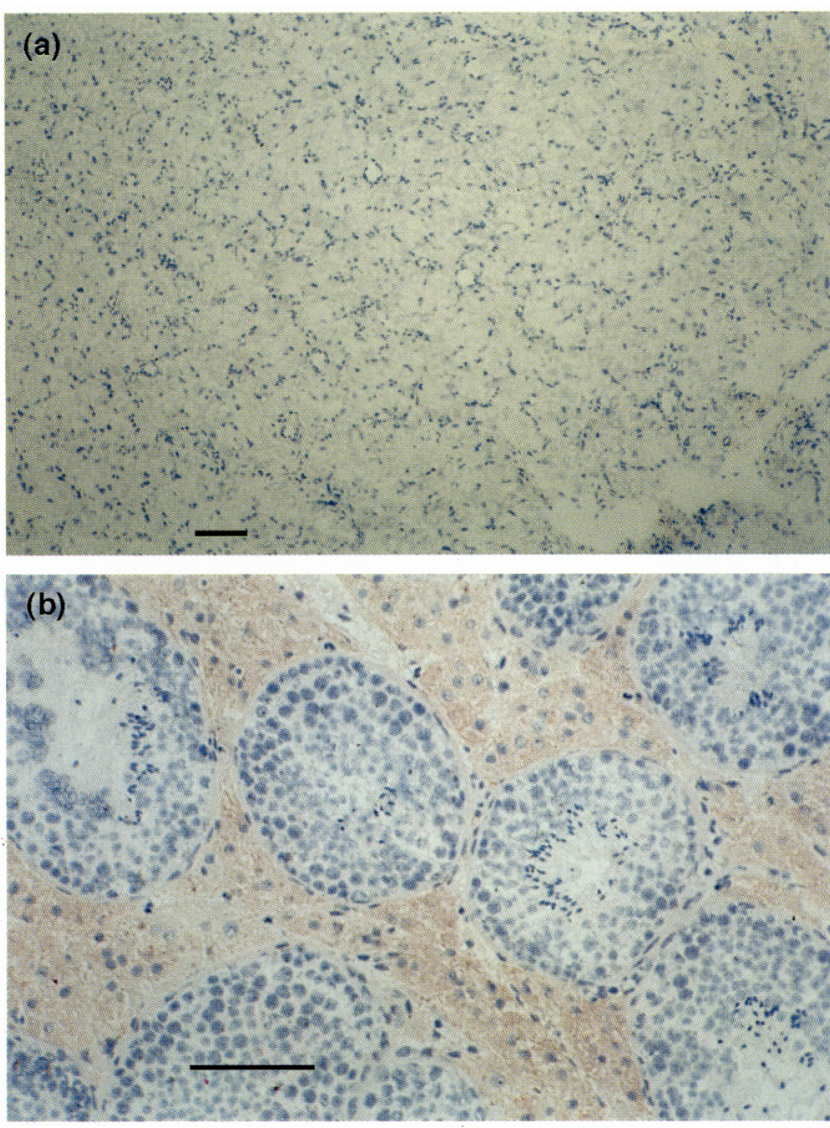

Fig. 5. (a) Negative control section of corpus luteum from the ovary of a mare in which the primary antibody for aromatase P-450 was excluded. (b) Positive control section of stallion testis. No immunostaining for aromatase P-450 was present in the seminiferous tubules, whereas the surrounding interstitial cells stained positive. Scale bars represent $10 \mu \mathrm{m}$.

1991). Culture of isolated cell types can be subject to contamination with other cell populations (Ryan and Short, 1965) and to changes that can transform cells in vitro such as the propensity for granulosa cells to luteinize in vitro (Channing, 1969). In situ detection of enzyme by immunohistochemical staining does not allow quantitation of enzyme content, but does localize the enzymes to specific cell types. The results of the present study would indicate, therefore, that aromatization of androgens is confined to granulosa cells within the follicle.

Most studies agree that oestradiol is not present in the corpus luteum of the nonpregnant mare (Short, 1964; Mahajan and Samuels, 1974); however, luteal cells and microsomes from corpora lutea appeared to be capable of aromatizing testosterone and androstenedione when these were provided as substrates (Mahajan and Samuels, 1974; Al-Timimi et al., 1989). Furthermore, the presence of oestradiol in the mid-luteal corpus luteum was reported by Younglai (1971) and there is unpublished circumstantial evidence that oestrogen secretion increases during the mid-luteal phase and decreases rapidly after administration of $\mathrm{PGF}_{2 u}$ (cited in Daels et al., 1991). We have shown that immunoreactive $\mathrm{P}-450_{\text {arom }}$ is present in luteal cells throughout dioestrus. Therefore, the potential for oestrogen production resides within the corpus luteum of the cyclic mare. Although thecal cells are present in the trabeculae of the mare corpus luteum (Harrison, 1946), and small luteal cells that might be expected to be of thecal origin are steroidogenic (Kelly et al., 1988; Broadley et al., 1994), the small thecalderived cells are vastly outnumbered by the large granulosaderived cells. As the granulosa-derived cells appear to depend on the theca-derived cells for androgen substrate, the ability of the corpus luteum to produce androgens and oestrogens may be directly related to the extent to which thecal cells contribute to the corpus luteum (Henderson and Swanston, 1978). However, there appear to be marked differences in steroidogenic capacities of ovarian cells among species (Hammerstein et al., 1964; Watson and Leask, 1975; Al-Timimi et al., 1989; Lautincik et al., 1994). Most studies have shown that the corpus luteum of the non-pregnant mare does not produce oestrogen. If this is the case, high concentrations of circulating progesterone during dioestrus could inhibit aromatase activity in the mare ovary (Amri et al., 1993) as has been proposed in sows (Gregoraszczuk, 1994) and rats (Fortune and Vincent, 1983). Therefore, factors other than cell type may influence luteal oestrogen production.

In the mare corpus luteum, immunostaining for $\mathrm{P}-450_{\text {arom }}$ was present shortly after luteolysis, whereas the human corpus luteum demonstrates neither P-450 arom immunoreactivity nor mRNA expression after luteal regression (Suzuki et al., 1993). However the corpora lutea examined by Suzuki et al. (1993) were probably older than the mare corpora lutea in the study reported here. The presence of immunoreactivity for aromatase in the mare corpora lutea in the period immediately after luteolysis, when steroid production ceases, suggests that cessation of steroidogenesis is dependent on mechanisms other than disappearance of aromatase. It is thought that $\mathrm{PGF}_{2 u}$ may cause luteolysis in domestic species by inhibition of second messenger pathways (Fletcher and Niswender, 1982) rather than by having a direct effect on steroidogenic enzymes.

The mare corpus luteum appears to comprise at least two distinct populations of large luteal cells. Some individual cells stained very heavily for aromatase, whereas the staining in surrounding cells was much weaker. Apparent differences in staining intensities within cell populations have similarly been reported in granulosa cells of preovulatory follicles of rats and mice (Ishimura et al., 1989), interstitial cells in stallion testes (Eisenhauer et al., 1995), and in theca interna cells in follicles of sheep and cattle (Conley et al., 1995), leading to suggestions that there may be functional differences within these populations. Although immunostaining is not a quantitative technique, a significant correlation has been shown between immunointensity for aromatase P-450, measured by computerized image analysis, and enzyme activity (Sasano, 1994). During early pregnancy the difference in staining between cells in the mare corpus luteum was less marked, whereas by day 40 , strong areas of staining had returned.

It seems likely that equine chorionic gonadotrophin (eCG), the concentration of which increases around day 35 of pregnancy, acts as the trigger for oestrogen production by the primary corpus luteum. Recent work has shown that treatment with eCG stimulates oestrogen secretion in pregnant mares with a corpus luteum, but not in those in which the corpus luteum has been removed (Daels and Albrecht, 1995). Luteal mRNA encoding aromatase P-450 in the mare corpus luteum 
was lower after the onset of eCG secretion than at any other stage during pregnancy, despite the increased oestrogen secretion (Albrecht et al., 1995). This observation led to the suggestion that the increase in luteal oestrogen secretion is due to post-transcriptional regulation of aromatase activity by eCG (Albrecht et al., 1995). However, there is usually a good correlation between concentrations of mRNA encoding aromatase P-450 and amount of enzyme protein (Doody et al., 1990). The results reported here show the appearance of darker staining in certain individual cells after the onset of eCG secretion, which might indicate that these cells were producing more aromatase than earlier in pregnancy, but the pattern and intensity of staining was not different from that shown by corpora lutea from non-pregnant mares. These data suggest that $\mathrm{P}-450_{17 \text { u }}$ activity, which provides the androgen substrate, may be the important limiting factor in secretion of oestrogen by the corpus luteum of pregnant mares. The appearance of $\mathrm{P}-45 \mathrm{O}_{17 u}$ in luteal cells may be stimulated by eCG. Indeed $\mathrm{P}-45 \mathrm{O}_{17 \mathrm{a}}$ has been induced in thecal cells of immature rats by treatment with eCG and hCG (Ishimura et al., 1990), and injection of rats with eCG increased total hybridizable transcript for P-450 $17 u$ (Doody et al., 1991). We have preliminary evidence that $\mathrm{P}-45 \mathrm{O}_{17 \mathrm{u}}$ is present in the corpus luteum during pregnancy but not during the oestrous cycle (Rodger et al., 1995). Similarly a previous report has described low 17,20 lyase activity of corpora lutea from non-pregnant mares as demonstrated by the poor capacity of luteal tissue to metabolize progesterone to androgens (Mahajan and Samuels, 1974), although another study showed that low concentrations of androgens were produced (Al-Timimi ef al., 1989).

The biological significance of any oestrogen secretion by the primary corpus luteum is questionable as it is well documented that mares ovariectomized on day 34 or 35 of pregnancy and supplemented with only progestagens can maintain a pregnancy until placental steroid production takes over at around day 100 (Shideler et al., 1982).

Ovarian tumours are relatively common in mares and account for approximately $5.6 \%$ of all neoplasms (Righ et al., 1985). By far the commonest type of ovarian neoplasm is the granulosa cell tumour (McEntee, 1990). The failure of the tissue from two of the granulosa cell tumours to show significant immunostaining and the low level of staining in the other is interesting and is similar to immunostaining of human granulosa cell tumours (Sasano, 1994). The high circulating oestrogen concentrations present in some women with granulosa cell tumours (Besch et al., 1966) are not characteristic of this tumour in mares (Stabenfeldt et al., 1979). However, the tumour from the mare that had higher concentrations of circulating oestradiol showed a greater degree of immunostaining. It has been suggested that aromatization of testosterone to oestradiol may be low in granulosa cell tumours (Stabenfeldt et al., 1979) and our results showed that very little aromatase was present.

The results from the present study showed good agreement between expression of P-450 arom and recent reports of steroidogenesis by isolated cell types in vitro. Together with our previous results showing staining for $\mathrm{P}-45 \mathrm{O}_{17 u}$ in theca interna cells of preovulatory follicles (Rodger et al., 1995), we have confirmed that the two-cell theory of steroidogenesis, in which thecal androgen is aromatized by granulosa cells (McNatty et al., 1979; Hillier, 1981), applies to the mare ovary.
The authors would like to thank E. Nikolakopoulos, D. Lawler and M. Jordan for assistance with the mares. C. Gerstenberg (Equine Fertility Unit, Newmarket, UK) kindly provided material from one of the pregnant mares. The aromatase antibody was generously donated by E. Simpson (University of Texas).

\section{References}

Al-Timimi I, Gaillard JL, Amri H and Silberzahn P (1989) Androgen synthesis and aromatization by equine corpus luteum microsomes Journal of Biological Chemistry $2647161-7168$

Albrecht BA, MacLeod JN and Daels PF (1995) Cytochrome P450 aromatase mRNA levels decrease in equine luteal tissue after the onset of chorionic gonadotropin secretion Biology of Reproduction 52 (Supplement 1) Abstract 221

Amri H, Silberzahn P, AI-Timimi I and Gaillard J (1.993) Aromatase activity in the mare ovary during the estrous cycle. Measurement of endogenous steroids and of their in vitro inhibitory effect Acta Endocrinologica 129 $536-542$

Besch PK, Watson DJ, Vorys N, Hamwi GJ, Barry RD and Barnett EB (1966) In vitro biosynthetic studies of endocrine tumors American Journal of Obstetrics and Gynecology 96 466-477

Broadley C, Menzies GS, Bramley TA and Watson ED (1994) Isolation of cell populations from the mare corpus luteum: comparison of mechanical and collagenase dissociation Journal of Reproduction and Fertility 102 7-15

Channing CP (1969) Studies on tissue culture of equine ovarian cell types: pathways of steroidogenesis Journal of Endocrinology 43 403-414

Channing $\mathrm{CP}$ and Grieves SA (1969) Studies on tissue culture of equine ovarian cell types: steroidogenesis Journal of Endocrinology 43 391-402

Conley AJ, Kaminski MA, Dubowsky SA, Jablonka-Shariff A, Redmer DA and Reynolds LP (1995) Immunohistochemical localization of $3 \beta$-hydroxysteroid dehydrogenase and P450 17a-hydroxylase during follicular and luteal development in pigs, sheep and cows Biology of Reproduction 52 1081-1094

Daels PF and Albrecht BA (1995) Equine chorionic gonadotropin (eCG) regu lates luteal steroidogenesis in mares Biology of Reproduction 52 (Supplement 1) Abstract 221

Daels PF, DeMoraes JJ, Stabenfeldt GH, Hughes JP and Lasley BL (1991) The corpus luteum: source of oestrogen during early pregnancy in the mare Journal of Reproduction and Fertility Supplement 44 501-508

Doody KJ, Lorence MC, Mason J and Simpson ER (1990) Expression of messenger ribonucleic acid species encoding steroidogenic enzymes in human follicles and corpora lutea throughout the menstrual cycle Journal of Clinical Metabolism 70 1041-1045

Doody KJ, Lephart ED, Stirling D, Lorence MC, Magness RR, McPhail MJ and Simpson ER (1991) Expression of mRNA species encoding steroidogenic enzymes in the rat ovary Journal of Molecular Biology 6 153-162

Eisenhauer KM, McCue PM, Nayden DK, Osawa Y and Roser JF (1995) Localization of aromatase in equine Leydig cells Domestic Animal Endocrinology 11 291-298

Fletcher PW and Niswender GD (1982) Effect of PGF-2 $\alpha$ on progesterone secretion and adenylate cyclase activity in ovine luteal tissue Prostaglandins $20803-818$

Fortune JE and Vincent SE (1983) Progesterone inhibits the induction of aromatase activity in rat granulosa cells in vitro Biology of Reproduction $\mathbf{2 8}$ 1078-1089

Gregoraszczuk EL (1994) Is progesterone a modulator of luteal steroidogenesis in the pig? A tissue culture approach Folia Histochemica et Cytobiologian 32 $31-33$

Hammerstein J, Rice BF and Savard K (1964) Steroid hormone formation in the human ovary: I. Identification of steroids formed in vitro from acetate- $1-{ }^{14} \mathrm{C}$ in the corpus luteum Journal of Clinical Endocrinology and Metabolism 24 $597-605$

Harrison RJ (1946) The early development of the corpus luteum Journal of Anutomy $\mathbf{8 0} 160-168$

Hay MF, Allen WR and Lewis IM (1975) The distribution of $\Delta^{5}-3 \beta$ hydroxysteroid dehydrogenase in the Graafian follicle of the mare Joumal of Reprotuction and Fertility Supplenent $23323-327$

Henderson KM and Swanston IA (1978) Androgen aromatization by luteinized bovine granulosa cells in tissue culture Journal of Reproduction and Fertility $\mathbf{5 2}$ $131-134$ 
Hillier SG (1981) Regulation of follicular oestrogen biosynthesis: a survey of current concepts Journal of Endocrinology 89 3-18

Ishimura K, Yoshinaga-Hirabayashi T, Touri H, Fujita H and Osawa Y (1989) Further immunocytochemical study on the localization of aromatase in the ovary of rats and mice Histochemistry $90413-416$

Ishimura K, Yoshinaga-Hirabayashi T, Tsuri $\mathrm{H}$, Kominami S, Takemori $\mathrm{S}$ and Fujita $H$ (1990) Immunohistochemical and biochemical studies on the localization and changes of $17 \alpha$-hydroxylase/C17-C20 lyase activity in immature rat ovary treated with PMSG and hCG Histochemistry 94 225-229

Kelly CM, Hoyer PB and Wise ME (1988) In-vitro and in-vivo responsiveness of the corpus luteum of the mare to gonadotrophin stimulation Journal of Reproduction and Fertility 84 593-600

Kenney RM, Condon W, Ganjam VK and Channing C (1979) Morphological and biochemical correlates of equine ovarian follicles as a function of their state of viability or atresia Journal of Reproduction and Fertility Supplement 27 $163-171$

Lautincik J, Kolodzieyski L, Elias V, Hyttel P, Osawa Y and Sirotkin A (1994) Immunocytochemical localization of aromatase in the ovary of superovulated cattle, pigs and sheep Acta Veterinaria Scandinavia 35 185-191

McEntee K (1990) Ovarian Neoplasms. In Reproductive Pathology of Domestic Animals pp 69-93 Academic Press Inc., London

McNatty KP, Makris A, De Grazia C, Osathanondh R and Ryan KJ (1979) The production of progesterone, androgens, and estrogens by granulosa cells, thecal tissue and stromal tissue from human ovaries in vitro Journal of Clinical Endocrinology and Metabolism 49 687-699

Mahajan DK and Samuels LT (1974) The steroidogenic ability of various cell types of the equine ovary Steroids 24 713-730

Righ DG, Bowen JM and Gaughan EM (1985) Equine ovarian tumors Compendium on Continuing Education for the Practicing Veterinarian 7 5710-5716

Rodger FE, Illingworth PJ and Watson ED (1995) Immunolocalisation of 17- $\alpha$ hydroxylase in mare ovary Journal of Reproduction and Fertility Abstract Series 15 Abstract 79

Ryan KJ and Short RV (1965) Formation of estradiol by granulosa and theca cells of the equine ovarian follicle Endocrinology 76 108-114

Sasano H (1994) Functional pathology of human ovarian steroidogenesis: normal cycling ovary and steroid-producing neoplasms Endocrine Pathology 5 $81-89$

Shideler RK, Squires EL, Voss JL, Eikenberry DJ and Pickett BW (1982) Progestagen therapy of ovariectomized pregnant mares Journal of Reproduction and Fertility Supplement 32 459-464

Short RV (1961) Steroid concentrations in the follicular fluid of mares at various stages of the reproductive cycle Journal of Endocrinology 22 153-163
Short RV (1962) Steroids in the follicular fluid and the corpus luteum of the mare. A 'two-cell type' theory of ovarian steroid synthesis Journal of Endocrinology 24 59-63

Short RV (1964) Ovarian steroid synthesis and secretion in vivo Recent Progress in Hormone Research 20 303-340

Simpson ER, Mahendroo MS, Means GD, Kilgore MW, Hinshelwood MM Graham-Lorence S, Amanch B, Ho Y, Fisher C, Michael MD, Mendelson CR and Bulun SE (1994) Aromatase cytochrome P450, the enzyme responsible for estrogen biosynthesis Endocrine Reviews 15 342-355

Sirois J, Kimmich TL and Fortune JE (1991) Steroidogenesis by equine preovulatory follicles: relative roles of theca interna and granulosa cells Endocrinology 128 1159-1166

Stabenfeldt GH, Hughes JP, Kennedy PC, Meagher DM and Neely DP (1979) Clinical findings, pathological changes and endocrinological secretory patterns in mares with ovarian tumours Journal of Reproduction and Fertility Supplement $27277-285$

Sundberg JP (1977) Neoplasms of Equidae Joumal of the American Veterinary Medical Association 170 150-151

Suzuki T, Sasano $\mathbf{H}$, Tamura M, Aoki H, Fukaya T, Yajima A, Nagura $\mathbf{H}$ and Mason JI (1993) Temporal and spatial localisation of steroidogenic enzymes in premenopausal human ovaries: in situ hybridisation and immunohistochemical study Endocrinology 97 135-143

Tucker KE, Henderson KA and Duby RT (1991) In vitro steroidogenesis by granulosa cells from equine pre-ovulatory follicles Journal of Reproduction and Fertility Supplement 44 45-55

Van Rensburg SJ and Van Niekerk CH (1968) Ovarian function, follicular oestradiol-17 $\beta$, and luteal progesterone and 20a-hydroxy-pregn-4-en-3-one in cycling and pregnant equines Onderstepoort Journal of Veterinary Research 35 301-308

Watson J and Leask JTS (1975) Superfusion in vitro in the study of ovarian steroidogenesis Journal of Endocrinology 64 163-173

Watson ED and Sertich PL (1990) Secretion of prostaglandins and progesterone by cells from corpora lutea of mares Journal of Reproduction and Fertility $\mathbf{8 8}$ 223-229

Watson ED and Thomson SRM (1996) Lymphocyte subsets in the endometrium of genitally-normal and susceptible mares Equine Veterinary Journal $\mathbf{2 8}$ 106-110

Watson ED, Colston M and Broadley C (1995) LH and progesterone concentrations during diestrus in the mare and the effect of hCG Theriogenology 43 1325-1338.

Younglai EV (1971) Steroid content of the equine ovary during the reproductive cycle Journal of Endocrinology 50 589-597 